\title{
The Effect of Fat Composition to Liver Enzymes, Cholesterol, Triglyceride and Liver MDA Levels in Wistar Strain Rats Which is Induced by High Fat Diet
}

\author{
Fransiska Ambarukmi Pontjosudargo* \\ Department of Anatomy, Faculty of Medicine \\ University of Jenderal Achmad Yani \\ Cimahi, Indonesia \\ *fransiska.ambarukmi@lecture.unjani.ac.id
}

\section{Evi Sovia}

Department of Pharmacology, Faculty of Medicine University of Jenderal Achmad Yani

Cimahi, Indonesia

soviaevi@yahoo.com

\author{
Hendri Priyadi \\ Department of Internal Medicine, Faculty of Medicine \\ University of Jenderal Achmad Yani \\ Cimahi, Indonesia \\ henpri74.hp@gmail.com
}

Lia Siti Halima

Department of Microbiology, Faculty of Medicine University of Jenderal Achmad Yani

Cimahi, Indonesia

lia.dio28@gmail.com

\author{
Endry Septiadi \\ Department of Nutrition, Faculty of Medicine \\ University of Jenderal Achmad Yani \\ Cimahi, Indonesia \\ endry.idol@gmail.com
}

\begin{abstract}
Research to assess liver damage has been widely studied, but intervention models of liver damage still use hepatotoxic substances. The important thing in research on Non Alcoholic Fatty Liver Disease, is that it is difficult to compare the results of the studies, because the variety of studies is very diverse. The description of diet composition that uses fat content as the main source of calories is neglected. The target of this study is to obtain scientific information regarding the composition of fat diet which can be used to induce dyslipidemia and liver damage. The study used 15 rats with the number of replications for each group was 3 rats in 5 groups consisting of negative controls, groups that were given a diet of $50 \%, 60 \%$, $70 \%$ and $80 \%$ fat for 2 weeks. The indicators assessed were lipid profiles including triglyceride levels, total cholesterol, SGPT enzyme levels and liver MDA. The data obtained were analyzed using One Way Anova and Duncan's test, with a confidence degree of $95 \%$. The results showed that giving a high-fat diet with a composition of up to $80 \%$ fat did not result in a significant increase in triglyceride levels, but resulted in a significant increase in liver cholesterol, SGPT and MDA levels. The diet with a composition of $50 \%$ fat for 2 weeks increased cholesterol and liver MDA levels which was significantly different from the control group, whereas a significant increase in SGPT levels was seen in the group given a $70 \%$ high-fat diet. Giving a high-fat diet for 2 weeks can increase cholesterol, SGPT enzymes and liver
\end{abstract}

MDA levels, but is not able to increase triglyceride levels significantly.

Keywords—high fat diet, cholesterol, liver MDA, SGPT, triglyceride

\section{INTRODUCTION}

Nonalcoholic Fatty Liver Disease (NAFLD) is increasingly recognized as the leading cause of morbidity and mortality of liver disease. The prevalence of NAFLD increases along with the increase in obesity. Data shows, fatty liver occurs in 10$15 \%$ of normal individuals, and $70-80 \%$ of obese people. Approximately $3 \%$ of normal individuals and $15-20 \%$ of obese people (BMI over $35 \mathrm{~kg} / \mathrm{m} 2$ ) have steatohepatitis [1-3].

The accumulation of fat in the liver is the initial stage of the occurrence of NAFLD. This is due to the intense accumulation of triglycerides caused by the imbalance between influx and free fatty acid synthesis in the liver, the process of $\beta$-oxidation and transport to outside cells arising from various causative factors. The next stage occurs liver steatosis which leads to the process of scarring and inflammation of liver cells and ends with the formation of scarring or fibrosis. Factors thought to trigger this process are oxidative stress, chain lipid 
peroxidation, $\mathrm{TNF}-\alpha$, and hormones associated with adipose tissue. NAFLD represents the presence of metabolic syndrome in liver components, which occurs in people with obesity, hyperinsulinemia, peripheral insulin resistance, diabetes, hypertriglyceridemia, and hypertension $[3,4]$.

Management of NAFLD requires long-term monitoring. Supportive therapy is done by losing weight for people with obesity and lifestyle modification. Pharmacological therapy is only given to those who have not improved by making lifestyle changes, and the results are not necessarily satisfactory, because generally, the treatment of this disease requires multiple therapies. Various studies have been conducted to be able to find the most effective therapy in the treatment of NAFLD. Generally, research was conducted at the preclinical stage, using induction models with a diet of high-fat levels as the main source of energy in food, as a trigger for the occurrence of early mechanisms causing the onset of fatty liver $[2,4,5]$.

One of the important things to criticize in research that reviews the treatment of diseases due to a high-fat diet is the difficulty of comparing the results of studies conducted due to the variety of diverse research. Often researchers ignore the description of the diet composition of the control group and the treatment group that uses fat content as the primary source of calories. Pamella in her 2016 study that reviewed the effects of high-fat diets on bioenergetic and oxidative rewards on the liver of mice revealed, various research articles that present experimental designs with high-fat dietary interventions, generally using the fat composition as much as $30-60 \%$ in their diet in both rats and mice. Research conducted by Gaemers et al. in 2011, to cause fatty liver conditions in mice was conducted high-fat dieting for from 3 to 12 weeks [6-9].

The standard composition of a high-fat diet that is able to give rise to a picture of fatty liver, its effect on liver enzyme levels, and MDA, as well as to the picture of lipid profiles in the blood is associated with the length of administration is still not found, due to its wide variation. Similarly, the duration of treatment varies greatly [10-13]. On that basis, it is necessary to research the Influence of Fat Content Composition on The Picture of Liver Histopathology, Liver Enzyme Levels, Lipid Profile, and MDA in Wistar Strain Rats Induced High Fat Diet. The purpose of this study was to find out the influence of a diet high in fat composition of $50 \%, 60 \%, 70 \%$, and $80 \%$ on lipid profiles, SGPT enzyme levels, and MDA liver of Wistar strain male rats given during 2 weeks of treatment.

\section{MATERIAL AND METHODS}

Research is experimentally laboratory with comparative methods. The object of the study was 15 male mice Wistar strain that has been adapted for 7 days. The grouping of mice consisted of 5 groups with each group consisting of 3 mice, which were divided into negative control groups that given only standard feeding and drinking, and the treatment group was given a high-fat diet with a fat composition of $50 \%, 60 \%$, $70 \%$, and $80 \%$. This research has obtained ethics approval from the Ethics Committee of Universitas Padjadjaran Bandung Indonesia.

At the stage of treatment, mice that had been distributed into their groups were given appropriate treatment with the group. The creation of a high-fat diet was carried out with the composition as in Table 1, which was conducted a proximate test to ensure the levels of fat contained in per 100 grams of food to be orally fed in mice every day, for 2 weeks. After conducting measurements of triglyceride levels, cholesterol, SGPT enzymes, and liver MDA, the data obtained were analyzed using One Way ANOVA and continued with Duncan's post hoc test.

TABLE I. Composition of FAt CONTENT in Food Given In Mice

\begin{tabular}{|l|l|l|l|l|l|}
\hline \multicolumn{1}{|c|}{ Compotitions } & $\begin{array}{c}\text { Standard } \\
\text { Diet }\end{array}$ & $\begin{array}{c}\text { Diet } \\
\mathbf{1}\end{array}$ & $\begin{array}{c}\text { Diet } \\
\mathbf{2}\end{array}$ & $\begin{array}{c}\text { Diet } \\
\mathbf{3}\end{array}$ & $\begin{array}{c}\text { Diet } \\
\mathbf{4}\end{array}$ \\
\hline Protein $(\mathrm{g})$ & 20 & 20 & 20 & 20 & 10 \\
\hline Carbohydrates $(\mathrm{g})$ & 60 & 20 & 10 & 0 & 0 \\
\hline Fat $(\mathrm{g})$ & 10 & $\mathbf{5 0}$ & $\mathbf{6 0}$ & $\mathbf{7 0}$ & $\mathbf{8 0}$ \\
\hline Fiber $(\mathrm{g})$ & 4 & 4 & 4 & 4 & 4 \\
\hline Mineral mix $(\mathrm{g})$ & 4 & 4 & 4 & 4 & 4 \\
\hline Vitamin mix $(\mathrm{g})$ & 1 & 1 & 1 & 1 & 1 \\
\hline Additional Materials & 1 & 1 & 1 & 1 & 1 \\
\hline Total $(\mathrm{g})$ & 100 & 100 & 100 & 100 & 100 \\
\hline
\end{tabular}

\section{RESULTS AND DISCUSSION}

Average levels of triglycerides, cholesterol, SGPT enzymes, and liver MDA in the control group and the dosing group with a high-fat diet composition of $50 \%, 60 \%, 70 \%$, and $80 \%$ showed differences. On a high-fat diet for two weeks, showed levels of triglycerides, cholesterol, SGPT enzymes, and liver MDA that increased along with an increase in the percentage of fat in the composition of the given diet. The highest value of all test parameters, produced by the diet-fed treatment group with the highest fat content, was $80 \%$. It can be seen in Table 2 .

Based on the results of the One Way Anova test in Table 3, the $\mathrm{p}$-value for the triglyceride parameter was $0.175(\mathrm{p}>0.05)$. It showed no significant differences among the group given a high-fat diet with varying fat percentage compositions and also in the standard feed control group. It means that a high-fat diet up to the highest percentage of $80 \%$ for two weeks has not sufficiently increased triglyceride levels significantly different from the standard group, as well as with other fat percentage groups. Anova's one-way test for cholesterol levels yielded values $p=0.014$, SGPT $p=0.013$, and MDA $p=0.006$. The $p$ values in the three variables are $p<0.05$, which means there were differences between the treatment groups for the threeparameter checks.

TABLE II. THE AVERAGE OF TRIGRLYCERIDE, CHOLESTEROL, SGPT ENZYM, AND LIVER MDA LEVELS IN TREATMEN GROUPS

\begin{tabular}{|l|l|l|l|l|l|l|}
\hline Variables & Standard & $\begin{array}{c}\text { Diet 1 } \\
\mathbf{( 5 0 \% )}\end{array}$ & $\begin{array}{c}\text { Diet 2 } \\
\mathbf{( 6 0 \% )}\end{array}$ & $\begin{array}{c}\text { Diet 3 } \\
\mathbf{( 7 0 \% )}\end{array}$ & $\begin{array}{c}\text { Diet 4 } \\
\mathbf{( 8 0 \% )}\end{array}$ & Mean \\
\hline Triglyceride & 55.91 & 98.26 & 118.36 & 132.11 & 135.47 & 108.02 \\
\hline Cholesterol & 52.87 & 70.85 & 74.65 & 74.85 & 77.04 & 70.05 \\
\hline SGPT Enzym & 35.95 & 40.05 & 52.15 & 57.19 & 69.83 & 51.04 \\
\hline Liver MDA & 7.18 & 12.11 & 12.59 & 15.12 & 15.74 & 12.55 \\
\hline
\end{tabular}




\section{*Information}

Diet 1: Fat Composition 50\%, Diet 2: Fat Composition $60 \%$

Diet 3: Fat Composition 70\%, Diet 4: Fat Composition $80 \%$

TABLE III. ONE WAY ANOVA TEST RESUltS ON 2 WEEKS OF TREATMENT

\begin{tabular}{|l|l|l|}
\hline \multicolumn{1}{|c|}{ Variables } & \multicolumn{1}{c|}{ Mean } & \multicolumn{1}{c|}{ p Value } \\
\hline Triglycerides & $108.02 \pm 45.34$ & 0.172 \\
\hline Cholesterol & $70.05 \pm 11.04$ & 0.014 \\
\hline SGPT Enzym & $51.04 \pm 15.17$ & 0.013 \\
\hline Liver MDA & $12.55 \pm 3.66$ & 0.006 \\
\hline
\end{tabular}

Post-Hoc Duncan's advanced test results for variable cholesterol levels showed a group divided into two subsets (Table 4). The first subset consisted of a control group that got standard feed, while the second subset consisted of the entire treatment group that got a fat diet with a composition of $50 \%$, $60 \%, 70 \%$, and $80 \%$ fat. It shows that there were significant differences in cholesterol levels in the control group with the treatment groups. While among the four treatment groups themself, there was no meaningful difference in cholesterol levels, because they were in the same subset. That is, the administration of a high-fat diet of good composition $50 \%$, $60 \%, 70 \%$, and $80 \%$ fat during the two weeks treatment does not give a noticeable difference to the blood cholesterol levels produced. This indicates that dieting with a fat composition of $50 \%$ for two weeks is enough to increase cholesterol levels significantly different from the group given a standard feed diet, and the resulting cholesterol levels are no different from the higher fat composition.

TABLE IV. DUNCAN'S ADVANCED TEST OF RAT CHOLESTEROL LEVELS AT 2 WEEKS TREATMENT

\begin{tabular}{|l|l|l|l|}
\hline \multirow{2}{*}{ Groups } & \multirow{2}{*}{$\mathbf{N}$} & \multicolumn{2}{c|}{ Subset for alpha $=\mathbf{0 . 0 5}$} \\
\cline { 3 - 4 } & & \multicolumn{1}{|c|}{$\mathbf{I}$} & \multicolumn{1}{c|}{$\mathbf{2}$} \\
\hline Standard & 3 & 52.87 & \\
\hline Diet 50\% & 3 & & 70.85 \\
\hline Diet 60\% & 3 & & 74.65 \\
\hline Diet 70\% & 3 & & 74.85 \\
\hline Diet $80 \%$ & 3 & & 77.04 \\
\hline Sig. & & 1.000 & 358 \\
\hline
\end{tabular}

Dieting with a composition of $50 \%$ fat for two weeks is enough to produce an increase in liver MDA levels that differ significantly from the group given a standard feed diet, and resulting levels are no different from those given a diet with a higher fat percentage composition. It is shown in Table 6.

TABLE V. DUNCAN'S ADVANCED TEST OF RAT SGPT ENZYM LEVELS AT 2 WEEKS TREATMENT

\begin{tabular}{|l|l|l|l|c|}
\hline \multirow{2}{*}{ Groups } & \multirow{2}{*}{$\mathbf{N}$} & \multicolumn{3}{c|}{ Subset for alpha = 0.05 } \\
\cline { 3 - 5 } & & $\mathbf{1}$ & $\mathbf{2}$ & $\mathbf{3}$ \\
\hline Standar & 3 & 35.95 & & \\
\hline Diet 50\% & 3 & 40.05 & 40.05 & \\
\hline
\end{tabular}

\begin{tabular}{|l|l|l|l|l|}
\hline \multirow{2}{*}{ Groups } & \multirow{2}{*}{$\mathbf{N}$} & \multicolumn{3}{c|}{ Subset for alpha $=\mathbf{0 . 0 5}$} \\
\cline { 3 - 5 } & & \multicolumn{1}{c|}{$\mathbf{2}$} & \multicolumn{1}{c|}{$\mathbf{3}$} \\
\hline Diet $60 \%$ & 3 & 52.15 & 52.15 & 52.15 \\
\hline Diet $70 \%$ & 3 & & 57.19 & 57.19 \\
\hline Diet $80 \%$ & 3 & & & 69.83 \\
\hline Sig. & & .087 & .072 & .065 \\
\hline
\end{tabular}

In contrast to the results shown in the examination of SGPT levels. Post-Hoc Duncan's advanced test results in Table 5 show groups divided into three subsets. The first subset consisted of a standardized feed group and a group fed a highfat diet with a composition of $50 \%$ and $60 \%$. The second subset consisted of groups given a high-fat diet with a composition of $50 \%, 60 \%$, and $70 \%$. The third subset consisted of a group of dieting mice with a fat composition of $60 \%, 70 \%$, and $80 \%$. This suggests that dieting with a fat composition of $50 \%$ and $60 \%$ for two weeks, did not produce significantly different levels of SGPT with the group given a standard diet. Administration of a diet high in fat $50 \%$ and $60 \%$ for two weeks has not shown any impaired liver function.

TABLE VI. DUNCAN'S ADVANCED TEST OF RAT LIVER MDA LEVELS AT 2 WEEKS TREATMENT

\begin{tabular}{|c|c|c|c|}
\hline \multirow{2}{*}{ Groups } & \multirow{2}{*}{$\mathbf{N}$} & \multicolumn{2}{|c|}{ Subset for alpha $=0.05$} \\
\hline & & 1 & 2 \\
\hline Standar & 3 & 7.18 & \\
\hline Diet $50 \%$ & 3 & & 12.11 \\
\hline Diet $60 \%$ & 3 & & 12.59 \\
\hline Diet $70 \%$ & 3 & & 15.12 \\
\hline Diet $80 \%$ & 3 & & 15.74 \\
\hline Sig. & & 1.000 & .093 \\
\hline
\end{tabular}

Significant increases in SGPT levels with the control group occurred in groups with a high-fat diet of $70 \%$, but SGPT levels in this group did not differ significantly from the $50 \%$ and $60 \%$ fat diet groups. This indicates the composition of a diet high in fat $70 \%$ given for 2 weeks began to show the presence of impaired liver function. The highest SGPT levels were produced by the group who obtained a high-fat diet with a percentage of $80 \%$, which was different from other groups fed standard and a diet high in fat $50 \%$ and $60 \%$, but SGPT levels in the $80 \%$ fat diet group were no different from the $60 \%$ and $70 \%$ fat diet groups. SGPT levels that showed significant differences were between the standard group and the group given a diet high in fat of $70 \%$ and $80 \%$.

Based on the results of the analysis of the four variables studied, it showed that a high-fat diet with a duration of 2 weeks of administration did not result in a significant increase in triglyceride levels in contrast to the standardized feed group. The most common fat in the diet is neutral fat, known as triacylglycerol. Almost all fats in the diet, except for a few short-chain fatty acids, are absorbed from the intestine into the intestinal lymph. Most triacylglycerols (as exogenous lipids) during the digestive process will be decomposed into monoglycerides and free fatty acids. Monoglycerides and fatty acids after passing through intestinal epithelial cells will be synthesized back into new triacylglycerol molecules that enter the lymph in the form of small scattered droplets called a 
chylomicron. Administration of a high-fat diet will lead to an increase in the concentration of chylomicron in plasma by 1-2 percent of the total plasma within an hour after meals. Triasilgliserols synthesized in the liver (as endogenous lipids) are transported throughout the tissues by Very Low-Density Lipoprotein (VLDL). Triasilgliserol was subsequently released as fatty acid in extrahepatic tissue [12]. It took a longer induction time to produce high levels of triglycerides in rat plasma.

High-fat dieting can increase cholesterol levels in mice due to the high intake of fat from foods that are an exogenous source of fat levels in the blood. This is according to this study, where the administration of a high-fat diet with a fat composition of $50 \%$ for 2 weeks has resulted in significantly increased cholesterol levels compared to the group that got the standard diet. This is in line with the research conducted by Kaprinay et al. [14].

To increase the level of SGPT that is significantly different from the control group, a high fat composition is required by $70 \%$. A $70 \%$ high-fat diet was enough to produce a significant increase in SGPT levels in contrast to the group that got the standard diet, in the duration of treatment for two weeks. Increased levels of SGPT will occur if there is an intracellular release of enzymes into the blood caused by the necrosis of liver cells. Giving a high-fat diet of more than $70 \%$ within two weeks can cause fatty liver and other liver damage. Increased levels of liver MDA have occurred in the administration of a high-fat diet with a composition of $50 \%$ with a duration of treatment of 2 weeks. A high-fat diet causes a hyperlipidemic state that triggers an increase in oxidative stress in the liver, which is characterized by increased liver MDA levels $[15,16]$.

\section{CONCLUSION}

The composition of a high-fat diet up to $80 \%$ has not been effective in increasing the plasma triglyceride levels of rats with a duration of 2 weeks of administration, but to increase plasma cholesterol and liver MDA have been able to be obtained by giving a high-fat diet of $50 \%$. Meanwhile, increasing the levels of the SGPT enzyme can be effectively done by giving a high-fat diet of $70 \%$ for two weeks. Similar further studies can be carried out to determine the effect of a high-fat diet that most effectively affects body weight and blood glucose levels and its effect on liver histopathology so that this method can be used as a research standard with a highfat diet induction model.

\section{REFERENCES}

[1] S. Bellentani, G. Bedogni, L. Miglioli, and C. Tiribelli, "The epidemiology of fatty liver," European journal of gastroenterology \& hepatology, vol. 16, no. (11), pp. 1087-1093, 2004
[2] N. Chalasani, Z. Younossi, J.E. Lavine, M. Charlton, K. Cusi, M Rinella, ... and A.J. Sanyal, "The diagnosis and management of nonalcoholic fatty liver disease: practice guidance from the American Association for the Study of Liver Diseases," Hepatology, vol. 67, no. (1), pp. 328-357, 2018.

[3] M. Duvnjak, I. Lerotić, N. Baršić, V. Tomašić, L.V. Jukić, and V. Velagić, "Pathogenesis and management issues for non-alcoholic fatty liver disease," World journal of gastroenterology: WJG, vol. 13, no. (34), pp. 4539-4550. 2007

[4] C.C. Chiu, Y.H. Ching, Y.P. Li, J.Y. Liu, Y.T. Huang, Y.W. Huang, .. and H.L. Chuang, "Nonalcoholic fatty liver disease is exacerbated in high-fat diet-fed gnotobiotic mice by colonization with the gut microbiota from patients with nonalcoholic steatohepatitis," Nutrients, vol. 9, no. (11), p. 1220, 2017.

[5] C.P.M.S. Oliveira, A.M.M. Coelho, H.V. Barbeiro, V.M.R. Lima, F Soriano, C. Ribeiro, ... and F.J. Carrilho, "Liver mitochondrial dysfunction and oxidative stress in the pathogenesis of experimental nonalcoholic fatty liver disease," Brazilian journal of medical and biological research, vol. 39, pp. 189-194, 2006.

[6] P.A. Kakimoto and A.J. Kowaltowski, "Effects of high fat diets on rodent liver bioenergetics and oxidative imbalance," Redox biology, vol. 8, pp. 216-225, 2016.

[7] I.C. Gaemers, J.M. Stallen, C. Kunne, C. Wallner, J. van Werven, A Nederveen, and W.H. Lamers, "Lipotoxicity and steatohepatitis in an overfed mouse model for non-alcoholic fatty liver disease," Biochimica et Biophysica Acta (BBA)-Molecular Basis of Disease, vol. 1812, no. (4), pp. 447-458, 2011.

[8] M. Ritskes-Hoitinga and A. Chwalibog, "Nutrient requirements, experimental design, and feeding schedules in animal experimentation,' In Handbook of Laboratory Animal Science: Essential Principles and Practices, $3^{\text {rd }}$ edition, vol. I, no (1), pp. 307-32, 2002. US: CRC Press.

[9] S.E. Lee, K. Han, Y.M. Kang, S.O. Kim, Y.K. Cho, K.S. Ko, ... and Taskforce Team of Diabetes Fact Sheet of the Korean Diabetes Association, "Trends in the prevalence of metabolic syndrome and its components in South Korea: Findings from the Korean National Health Insurance Service Database (2009-2013)," PloS one, vol. 13, no. (3), p e0194490, 2018.

[10] Y.C. Shen, C.F. Chen, and W.F. Chiou, "Andrographolide prevent oxygen radical production by human neutrophils: possible mechanism (s) involved in its anti-inflammatory effect," British journal of pharmacology, vol. 135, no. (2), pp. 399-406, 2002.

[11] M. Harini and O.P. Astirin, "Kadar kolesterol darah tikus putih (Rattus norvegicus) hiperkolesterolemik setelah perlakuan VCO,” Asian Journa of Tropical Biotechnology, vol. 6, no. (2), pp. 53-58, 2009

[12] I.M.S. Harsa, "Efek pemberian diet tinggi lemak terhadap profil lemak darah tikus putih (Rattus norvegicus)," Jurnal Ilmiah Kedokteran, vol. 3, no. (1), pp. 21-28, 2014

[13] I. Tsalissavrina, D. Wahono, dan D. Handayani, "Pengaruh pemberian diet tinggi karbohidrat dibandingkan diet tinggi lemak terhadap kadar trigliserida dan HDL darah pada Rattus novergicus galur wistar,” Jurnal Kedokteran Brawijaya, vol. 22, no. (2), pp. 80-89, 2013.

[14] B. Kaprinay, B. Liptak, L. Slovak, K. Svik, V. Knezl, R. Sotnikova, and Z. Gasparova, "Hypertriglyceridemic rats fed high fat diet as a model of metabolic syndrome," Physiol. Res, vol. 65, no. (4), pp. S515-S518, 2016

[15] W.A. Wibowo, Pengaruh Pemberian Perasan Buah Mengkudu (Morinda citrifolia) terhadap Kadar SGOT dan SGPT Tikus Putih (Rattus norvegicus) Diet Tinggi Lemak. Doctoral dissertation, UNIVERSITAS AIRLANGGA, 2007.

[16] K.K. Hermawan, "Pengaruh Pemberian Ekstrak Air Kombinasi Daun Jati Belanda, Kemuning, Murbei, Dan Rimpang Bangle Terhadap Kadar Sod Dan Mda Hepartikus Dengan Diet Tinggi Lemak," Jurnal Biokomplemeter Medicin, vol. 6, no. (3), pp. 205-215, 2019. 